\title{
Rise, Fall, and Semiperipheral Development IN THE ANDEAN WORLD-SYSTEM
}

Darrell La Lone

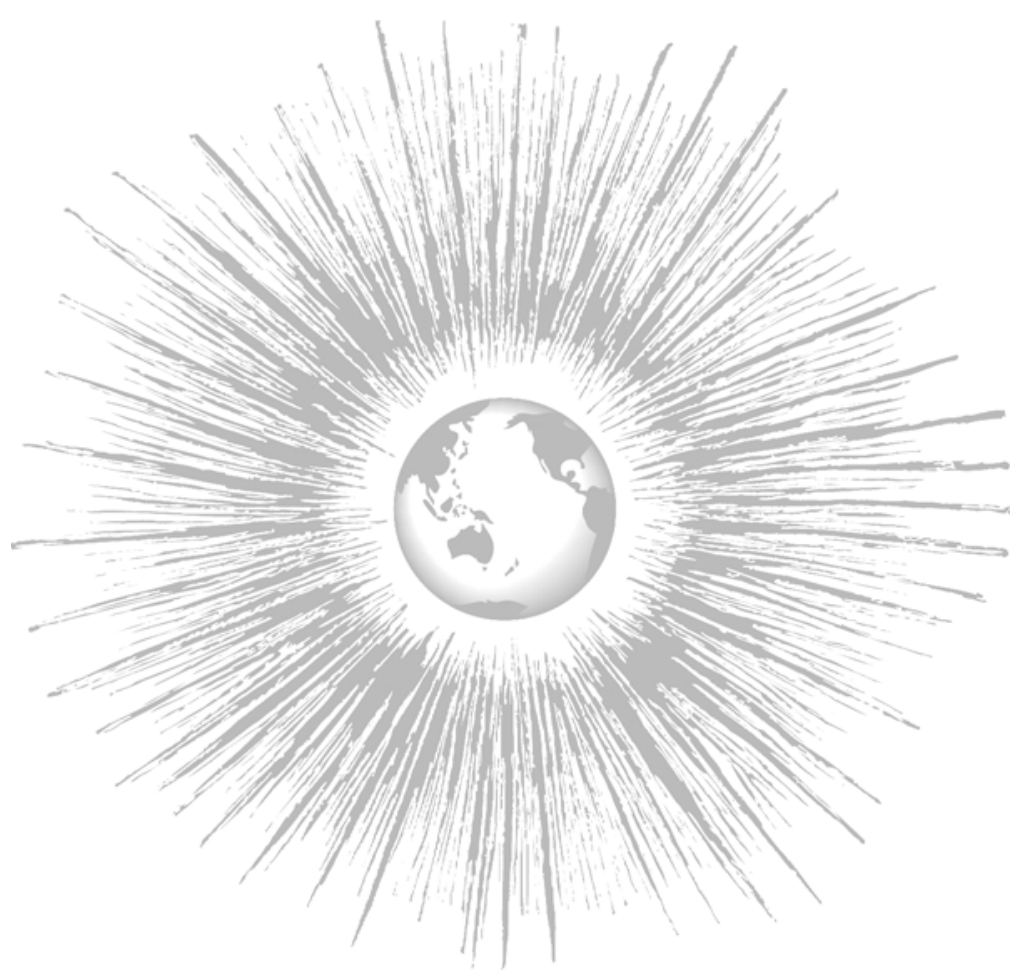

This paper examines how different power strategies have been played over the course of the three-thousand year Andean civilization. In broad terms, the power strategies center on ideological, economic, and military power (Mann 1986; Earle 1997). The case materials show that what we call "states" are formations that succeed, albeit temporarily, in combining strategies of ideological, economic, and military power. Nonetheless, following Randall Collins (1981:71), I would argue that coercive power is the sine qua non for state development. If we start from the power to coerce as a foundation, varying strategies of manipulating economic, ideological, and military power will produce a number of different pathways to varying forms of organization. Some may be more centralized than others, some may be less steeply stratified than others, some may have more specialized institutions than others, some may look more like environmental management systems, and others may look more like well-organized predatory protection rackets. Those which were less successful in manipulating these strategies were more vulnerable to collapse, opening the way for new formations to emerge. As world-systems approaches would predict, this has often happened on the peripheries of former core formations.

In common with many discussions of precapitalist world-systems the central problem I address is that of cycles of rise and fall in Andean civilizations. Such discussion of rise and fall is now well-established in worldsystems theory (Chase-Dunn and Hall 1997), but it has an even longer ancestry in archaeology and anthropology, where we have a rich literature on state formation and collapse (Yoffee 1995; Haas, Pozorski and Pozorski 1987; Wright and Johnson 1975; Jones and Kautz 1981; Culbert 1973; Marcus 1989; Millon 1988; Toland 1987; Carneiro 1970; Service 1975; Tainter 1988; Yoffee and Cowgill 1988). 
Before moving toward some of the particulars of Andean Civilization, it may first be useful to preview some of the larger lessons and warnings. First, our search for origins of "the" state has led us through a number of hypotheses. One of the most promising of these was the hydraulic hypothesis (Steward-Wittfogel), which made immensely great sense as logic and as an interpretation of Chinese history in particular (Wittfogel 1957). However, the hydraulic hypothesis has not fared well in empirical archaeological explorations of state origins (see, for example, (Adams 1966)). This is not to say that we should trash everything gained from it, but rather that it does not seem to be an accurate account of the early phases in state development. Nonetheless, it remains useful as a way of understanding some of the power strategies available to rulers.

Its most promising successor seemed to be Carneiro's model for population expansion and internecine conflict in circumscribed spaces. As was the case with the hydraulic hypothesis, Carneiro's model has considerable logical power. I comment on it in part because it seems to have been developed as a way of explaining state formation on the Peruvian coast. What may not be immediately apparent, though, is that it was not rooted in actual archaeological data from that region. When we examine the archaeological data from the Peruvian coast, we may well come back with reasons to question and challenge our confidence in the circumscription model. This is one example of how archaeological data may well be relevant to understanding long term change, but the lesson to be drawn is, perhaps, "Not So Fast"! This then leads us toward further exploration of a more complex relationship between warfare and state formation.

A further issue in state formation and collapse studies in archaeology underscores the appropriateness of world-systems analysis of rise and fall. A growing consensus in archaeology is that states are far more fragile than we might have thought after so much discussion of states as centralized management systems. The attainment of significant degrees of centralization is gained at considerable cost and against resistance from many sides.

Second, portrayal of states as management systems has been consistent with an emphasis on the connections between population expansion, intensification of production, environmental degradation and potential collapse, and pressures toward innovation in productive technologies that may sustain continuing population growth. Despite the apparent success of ecological systems approaches in terms of the elegance of their logic and their fruitfulness in generating research questions, archaeological evidence suggests a need to reconsider. For example, intensification of production may have less to do with the subsistence needs of a growing population of commoners than it does with the demands for prestige and wealth items from elites. Population expansion may not necessarily be a precursor to warfare but a consequence of warfare as a result of pressure to produce more orders on the part of elites, and a felt need on the part of commoners to replace sons. Conceptualizing states as management systems or problem solving organizations masks the inequalities characteristic especially in archaic states.

Third, my discussion of cycles of rise and fall in Andean polities draws upon insights from world-systems analysis on the importance of semiperipheries, and an important part of the overall dynamic is best understood from enduring principles of geopolitics. However, I would also acknowledge extensive independent discussions among archaeologists of cycles of rise and collapse around the world (see, for example, (Marcus 1998)). But, more specifically in regard to the Andean evidence, I would underscore another reason to be cautious. Many of our discussions of strategies in statecraft are based on the premise that states control contiguous territories. However, it has long been the case that Andean polities attempted to organize noncontiguous territories.

\section{Ups and Downs in the Andes}

Fifty years ago in his seminal paper on "Cultural Causality and Law," Julian Steward noted cycles in civilizations of the Americas which fluctuated between small regional polities and much larger social formations which we have come to call "Horizon Styles" (Steward 1949). This paper should be particularly intriguing for world-systems scholars because of its efforts to outline similar patterns of rise and fall in ancient civilizations around the world. More recently, Gordon Willey (1991) has revisited this theme in his paper on "Horizontal Integration and Regional Diversity: an Alternating Process in the Rise of Civilizations." In this essay, Willey observes that both in Mesoamerica and in the Andes we find alternations between horizontal integration and regional diversity. He offers as a thesis 
Table 1 - A Synoptic Chronology for the Central Andes

\begin{tabular}{|c|c|c|c|}
\hline Dates & Period & Core Politics & World-Systems Interactions \\
\hline $1438-1532$ & Late Horizon & Inca & $\begin{array}{l}\text { Pan-Andean Information, } \\
\text { prestige-goods, political-military, } \\
\text { bulk-goods and labor networks }\end{array}$ \\
\hline $1000-1438$ & Late Intermediate & $\begin{array}{l}\text { Chimu (North } \\
\text { Coast), Highland } \\
\text { "hill-fort } \\
\text { chiefdoms" (e.g. } \\
\text { Wanka, Chanka, } \\
\text { Quechua) }\end{array}$ & $\begin{array}{l}\text { Regional Information, prestige- } \\
\text { goods, political-military, and } \\
\text { bulk-goods networks }\end{array}$ \\
\hline $600-1000$ & Middle Horizon & Wari, Tiwanaku & $\begin{array}{l}\text { Pan-Highland (and some coastal) } \\
\text { information, prestige-goods, } \\
\text { political-military, bulk-goods } \\
\text { and labor networks }\end{array}$ \\
\hline $100-600$ & Early Intermediate & Moche, Nazca & $\begin{array}{l}\text { Multi-valley coastal (Moche) } \\
\text { information, prestige-goods, } \\
\text { political-military, and bulk- } \\
\text { goods networks }\end{array}$ \\
\hline $\begin{array}{l}800-100 \\
\text { CE }\end{array}$ & Early Horizon & Chavin & $\begin{array}{l}\text { Highland-based Pan-Andean } \\
\text { information and prestige-goods } \\
\text { networks }\end{array}$ \\
\hline $1800-800$ & Initial & Coastal Valleys & $\begin{array}{l}\text { Coastal intra-valley information } \\
\text { and bulk-goods networks }\end{array}$ \\
\hline $\begin{array}{l}3000-1800 \\
\mathrm{BCE}\end{array}$ & Late Preceramic & Coastal Valleys & $\begin{array}{l}\text { Coastal intra-valley information } \\
\text { networks }\end{array}$ \\
\hline
\end{tabular}

...that such an alternation of horizontal integration and regional diversity is a vital, perhaps even a necessary, process in the rise to that social, cultural, ideological, economic, and political complexity which, taken as a whole, we refer to as civilization" (Willey:197).

However, Willey's discussion of his thesis is largely descriptive, and invites other scholars to fill in more of the causal explanation for why such alternations occur and why they are such vital processes in civilizations.

The following pages offers a brief outline of these alternating cycles in Andean civilization. As the discussion is largely for the benefit of nonAndeanists, I will to avoid some of the highly specific and arcane archeological debates between Andeanists. Instead I will attempt to point out some of the more intriguing points of interest for the world-systems perspective.

THE LATE PRE-CERAMIC (300O-I8OO B.C.E*)

The late pre-ceramic is our starting point for the origins of complex societies in the Andes. During this period along the Peruvian coast we find our first evidence of monumental architecture. Some of these first monumental structures date back to 2500 B.C. E., so that they are roughly contemporaneous with the building of the pyramids in Egypt. One of the largest pre-ceramic sites is Aspero, in the Supe Valley on the north coast of Peru. Starting from about 2800 B.C.E., people at the Aspero site began to construct a number of large mounds, the largest of which, known as Huaca de los Idolos and Huaca de los Sacrificios measure some 30 by 50 meters. Walls were made of large blocks of basaltic rock, and a number of rooms were constructed on the summits (Morris and Von Hagen 1993:19). El Paraiso, the largest pre-ceramic site, in the Chillon Valley, dates to about 1800 B.C. E.. Here platform mounds and stone buildings were constructed out of more than 100,000 tons of quarried stone (Morris and Von Hagen: 39).

What we find particularly interesting in these data is first, that these very substantial monumental constructions are not associated with substantial residential debris. Second, although subsistence was based on some farming, there is no evidence for irrigation systems at this time. Third, although construction on this scale demonstrates significant labor mobilization, there is no evidence that labor mobilization was undertaken in order to intensify production in response to population increase. Fourth, although we have substantial labor mobilization, we have little evidence for social stratification in this era. And, finally, we are led to conclude that these large structures seem best interpreted as dedicated to public ceremonial purposes.

Some question the usefulness not simply of archaeological data for understanding long-term change, but also of the value of archaeological thinking. An old archaeological joke holds that when we don't know what something is, we simply say it must be ceremonial. However, what we find from excavations at Aspero is revealing evidence about construction techniques indicative of labor mobilization for public purposes. Buildings at Aspero were constructed with the use of bagged fill, a characteristic technique in sites of this era. Rubble was packed into "large open mesh satchels called shicra, made of coarse sturdy reeds and capable of holding as much as $26 \mathrm{~kg}$ of stone" (Moseley 1992:110). This promoted uniform units of construction in two senses: (1) structures were built from a known number of physical units, and (2) labor contributions could also be calculated in terms 
of such standard units. Although this and similar construction techniques characterize subsequent Andean public architecture, the bagged fill technique is not found in domestic architecture (Morris and Von Hagen 1993: 38).

The first traces of Andean civilization take the form of ceremonial monuments. The labor force necessary to construct the larger platform mounds must in many cases have been much larger than the nearby residential populations subsisting on sea resources and small-scale farming. People must have gathered from a wide area to pool their labor in the service of constructing a monument. And what, we might well ask, is the value of that? As Earle comments, "one factor common to all monuments... is their ability to be experienced simultaneously by large numbers of individuals" (Earle 1997:155).

As Earle argues, it is such common experiences that shape culture and culture change, rather than the ideas invoked mystically in the mentalist concept of culture that has for so long plagued anthropology. Monuments, and the common experiences they inspire, are examples of materialization. Again, as Earle explains,

Materialization is the transformation of ideas, values, stories, myths, and the like into physical reality that can take the form of ceremonial events, symbolic objects, monuments, and writing. It is the process by which culture is created, codified, and contained. Ideas and objects unite and are inseparable; ideas, unconnected to the object of world, have no means of being communicated, experienced, use, and owned. Ideas must be materialized to become social, to become cultural things. Our ideas are private and powerful for ourselves, but their materialization brings them into the public arena. (Earle 1997:151)

In the highlands also we find conspicuous Preceramic Period ceremonial sites such as Kotosh, La Galgada, and Huaricoto. Here, as on the coast, we find public architecture with numerous ritual chambers and remains of offerings. As on the coast, we have no evidence for dense settlement or social stratification.

\section{INITIAL PERIOD (I8OO-8OO B.C.E.)}

The Initial Period (also known as Early Ceramic) is marked by the appearance of ceramics, significant changes in settlement patterns, and the development of irrigated agriculture. Settlements moved from the early coastal settings into valleys allowing for irrigation agriculture. Pottery and cloth production on a large scale suggests craft specialization. For the most part, though, it appears that the gains from agricultural intensification were invested in bigger and better ceremonial structures. During this period we find the development of large U-shaped platform mounds that became characteristic along much of the Peruvian coast. Huge U-Shaped temple mounds were constructed at sites such as La Florida (in the Rimac Valley), Garagay (in the Chillon Valley), Cardal (in the Lurin Valley), Las Haldas (south of the Casma Valley) and Moxeke-Pampa de las Llamas (in the Casma Valley). At Sechin Alto, the platform mound measures 300 by 250 meters and rises 44 meters high (Morris and Von Hagen 1993:50).

The overall picture suggests that agricultural and labor intensification was invested in increasingly large ceremonial monuments. We have no evidence for political centralization and only scattered hints of social stratification suggested by a small number of burial offerings (Pozorski and Pozorski 1986). Overall, we find little evidence for trade, warfare, or political interactions between coastal valleys. Each valley appears to be relatively self-suffcient, and the only significant changes in settlement pattern are movements from the coastline to higher points in the middle and upper valleys. The spread of the large U-shaped platform mounds along much of the central and north-central coast shows no indication of political, military, or economic interactions between valleys. Nor do we have reason to suspect ideological interactions, since each center gives every appearance of being a local cult site.

How, then, might we account for the spread of a similar architectural form along the Peruvian coast? Two reasons come to mind. One, already discussed above, is that monuments are important because of "their ability to be experienced simultaneously by large numbers of individuals" (Earle 1997:155). In this way, monuments provide a focus for shared identity linking numerous small settlements scattered throughout each coastal valley. A corollary to such identity markers is that they also mark who does not belong. A highly visible monument also makes an important signal to outsiders concerning its makers' ability to mobilize substantial amounts of labor. Again, as Earle puts it,

Monuments convey a simple message of power and wealth (Trigger 1990). This elemental message comes across regardless of the viewer's language, age, gender, or cultural affiliation (Earle 1997:156) 
However, if the monuments of this era convey messages of power and wealth, we should not assume that power and wealth were politically or economically centralized. Apart from public monuments, we have none of the archaeological markers of state societies, and little evidence for the emergence of political or economic elites.

\section{EARLY HORIZON (8OO B+C.E+-IOO C*E*)}

Toward the beginning of the first millennium B.C.E., many of the coastal settlements seem to have collapsed. Between 900 and 700 B.C.E., construction was halted at the U-shaped complexes in the Lurin Valley and in many of the other ceremonial complexes of the central coast as well as along the north-central coast (Burger 1995:184-190). Although our current evidence concerning the causes of the collapse allows little more than speculation, I am inclined to the argument that demand both for subsistence and ceremonial construction pushed agricultural intensification toward increasingly higher yields, but coastal production was highly vulnerable to catastrophes (see Wilson 1999:352ff; Wilson 1981). In Peru catastrophes tend to be customary, taking such dramatically predictable forms as earthquakes, volcanic eruptions, landslides, massive floods, and of course catastrophes we term El Niño events. The Early Horizon marks a shift in focus of Andean civilization from the coast to the highlands, and from localized ceremonial centers to a pan-Andean cult. And it appears that this first major transformation in the development of Andean civilization emerges from a semiperipheral region.

The Chavin cult is named for its north-central highland type site, Chavin de Huantar, located at an altitude of over 3000 meters. This site extends for some 42 hectares, including the 5 hectare temple sector (Morris and Von Hagen 1993:56). Chavin seems clearly to have been a ceremonial center, though on a grander scale than its coastal precursors. A resident population of several thousand people built and served the center, but it seems clear that the center was not built to serve them. Unlike the coastal platform mounds which could "be experienced simultaneously by large numbers of individuals" (Earle 1997:155), Chavin offered a different form of cult experience. The Old Temple is a maze of rooms and passageways allowing access only to limited numbers of people at a time. Deep within its galleries are monolithic representations of the principal deities. Access to the cult images, and pre- sumably rituals, was exclusive rather than inclusive. It gives every appearance of a location for exclusive rituals, initiations, and oracular consultations. Yet this very closed cult became the first to span almost the entire length of the Andes and to reach down to the coast as well.

Chavin would certainly seem, nestled in its Andean heights, peripheral to the coastal valley communities. However, I believe the term semiperiphery is appropriate on several grounds. My usage of the term follows the broad outline of the terms offered in Chase-Dunn and Hall's Rise and Demise:

1. A semiperipheral region may be one that mixes both core and peripheral forms of organization.

2. A semiperipheral region may be spatially located between core and peripheral regions.

3. A semiperipheral region may be spatially located between two or more competing core regions.

4. Mediating activities between core and peripheral areas may be carried out in semiperipheral regions.

5. A semiperipheral area may be one in which institutional features are in some ways intermediate between those forms found in core and periphery (ChaseDunn and Hall 1997:37).

The structures at Chavin, including the U-shaped design of the Old Temple, would certainly seem familiar to any coastal visitor. However, the images and iconography of the temples reflect Amazonian tropical forest animals and stylistic motifs (definition 1). Chavin de Huantar is located high in the Andes between the coastal core region to the west and the peripheral tropical forest regions to the east (definition 2). The rituals performed at Chavin and then spread into core regions may well have been of tropical forest inspiration if not origin and very likely included use of tropical forest hallucinogens (definition 4).

Soon the images and stylistic conventions seen at Chavin de Huantar would spread throughout much of ancient Peru. Felines, caymans, the Chavin Staff God, and characteristic Chavin stylistic conventions were represented on ceramics, textiles, stone, and goldwork found in sites extending from the northern highlands to the south central coast. Our belief that this was a temple cult and not a military/political/economic movement is founded on the fact that the characteristic Chavin iconography is devoid of explicit references to political, military, or economic exploits of any sort. Chavin presence is expressed in ceramic and textile designs, but not in 
alteration of settlement patterns or any other indicator of invasion from an expansionistic polity. Andeanists of all theoretical persuasions share consensus that Chavin was a cult.

The expansion of the cult from the highlands to the coast does not take the form of monumental structures in Chavin style, but instead its presence is most often shown in portable objects representing Chavin iconography, and

these objects, judging from their form and decoration, appear to have functioned in ceremonial contexts as ritual paraphernalia or as part of the costumes of the officiants. Several classes of portable item are believed to be involved in the preparation and ingestion of hallucinogens (Burger 1988:124).

Apart from their association with a new iconographic tradition, many of these objects also demonstrate technological innovation. Both textiles and goldwork were produced in what some have characterized as "revolutionary" techniques. Textile production in the Chavin horizon underwent an

astonishing range of new techniques and materials first utilized as carriers of the Chavin designs. In fact, a set of inventions was promulgated whose influence obliterated most of the older textile traditions in the coastal areas, and which became the foundation for later Peruvian textile evolution (Conklin $1978: 1$ as cited in Burger 1988:129).

Goldworking also took forms never previously seen, and as the leading scholar of Andean metallurgy explains the new technologies,

It may be that in the Central Andes gold was used earlier than any other metal and that its prominence in the archaeological record during the period of spread and influence of the Chavin cult... reflects a religious and ceremonial bias of the cult for that metal... My feeling is that gold may have had special symbolic significance for the cult and that certain religious values ordoctrine were expressed through its use (Lechtman 1980 as cited in Burger 1988:130).

The Early Horizon then represents major transformations in the shape of Andean civilization. In the Preceramic and Initial periods, settlements and monumental ceremonial structures developed primarily on the coast. Little interaction was evident between valleys, but some exchange occurred between coastal valley settlements and their adjacent highlands. Thus, it seems appropriate to describe highland regions as semiperipheral. Then, following the collapse of the coastal communities at the end of the Initial
Period, the Chavin cult took off from its semiperipheral base to become the first nearly Pan-Andean core. In what was semiperiphery, we see revolutionary innovations in technology and ideology, and these innovations soon spread over much of the Peruvian Andes.

Again, I would emphasize that this expansion did not follow from the expansionistic moves of a centralized polity, nor did it seem to be driven by economic forces. If, as Andeanists argue, it was a cult, then we might ask why it had such wide appeal. Why would peoples of the coast or of the highlands trade their local cults for a foreign cult? Materialists have perhaps too often been misled by overly stubborn insistence on treating ideology as "mere" superstructure. As Earle points out,

Ideology is a system of beliefs and ideas presented publicly in ceremonies and other occasions. It is created and manipulated strategically by social segments, most importantly the ruling elite, to establish and maintain positions of social power. (Earle 1997:149)

Whatever led to the collapse of so many coastal communities, it seems reasonable to suspect that the local cults were unsuccessful in forestalling catastrophe. And,

....if the legitimacy of a center's cosmology was called into question, so too would the non-coercive authority of the leaders associated with this sacred knowledge. Ultimately, this would have undermined the very basis of the social relations that underlay the productive systems, and the functioning of these societies as viable units (Burger 1995:189).

Under these circumstances, perhaps a wonderful new cult might help ease people through times of crisis. However, we can find a better reason for the appeal of a new foreign cult, and that reason connects directly with the attempts of social segments to manipulate ideology to establish and maintain positions of social power. Over time, the ceremonies and rituals of the local cult would no longer serve communities in an egalitarian manner, if they ever did. If nothing else, with the establishment of new settlements at a greater distance from the ceremonial monument, people would be less immediately connected. Inevitably, some people would become disaffected, and it is precisely to such increasingly marginalized groups that a new foreign cult would appeal. As Elizabeth Colson notes,

The cult with universal claims then serves as a further court of appeals when a local cult does not satisfy its adherents... This was true in ancient 
Greece where each small city state had its own cult, associated with its fate as ahuman community, but delegations went to consult the Oracle of Delphi,or perhaps Dodona, which served the entire classical world for manycenturies. (Colson 1977:119 as quoted in Burger 1988:114).

Colson's reference to oracles such as Delphi and Dodona is not in the least far-fetched in regard to Andean civilization. One of the most ancient pilgrimage shrines in Andean civilization was the Oracle of Pachacamac, near Lima. Since it was still functioning at the time of the Spanish Conquest of Peru, we have ample ethnohistorical material on this Andean oracle. It is entirely reasonable to see Pachacamac as a parallel to Chavin.

The Chavin cult then offered a new basis for making claims to power. We may speculate that people who had made a pilgrimage to Chavin claimed special status. However, I think it is particularly significant that so many Chavin objects are portable, and that the major technological innovations of Chavin were in textiles and goldworking. This allowed the movement of high value/low bulk items over considerable distances, and the display of Chavin status items may have been an integral part of new claims to status and power.

It is, in fact, during the Early Horizon that we begin to see evidence for social stratification and wealth differentials, and

Significantly, many of the portable examples of Chavin religious art have been discovered in the rich burials of the upper social stratum. It is likely that these individuals used the ideology of the Chavin cult to legitimize and naturalize their wealth and positions of authority; indeed, the iconography of the cult frequently appears on jewelry and garments that these people wore. (Burger $1995: 203)$

Where this leaves us, then, is that the rise of a formerly semiperipheral area to the central core of a pan-Andean cult produced significant transformations in Andean civilization. New technologies did not increase subsistence production, but were directed toward production of prestige items. Such prestige items were important status markers and promoted competition among rival factions. This ideologically rooted movement initiated the first extensive long-distance exchange connections in the Andes and intensified the earliest movements toward control of political and economic power.

\section{THE EARLY INTERMEDIATE PERIOD (IOO-750 C.E*)}

By the end of the Early Horizon, Chavin de Huantar was no longer an important ritual center. Following its "collapse," the focus of Andean civilization shifted again to the coast. Although reasons for Chavin's decline may be pondered at length, I see the transition from Early Horizon to Early Intermediate as an unsurprising instance of pulsation in world-systems. Prior to Chavin's rise, coastal communities showed little stratification and appeared to be surprisingly egalitarian in view of their ability to mobilize substantial amounts of labor for community projects such as the large U-shaped mounds. These were in fact community projects and not directed toward private or elite interests. The rise of the Chavin cult and its impact on securing status markers heated up incipient factional rivalries. However, claims to power that rely primarily on status markers and prestige displays are fragile when not backed up by military and economic power strategies.

The end of the Early Horizon and the beginning of the Early Intermediate mark our first evidence for consolidation of political, military, and economic power as well as ideological power. It is during this period that we see the emergence of complex chiefdoms and archaic states. These polities were localized in the coastal valleys, until the Moche state established the first multi-valley (conquest) state in the Andes. In any event, Chavin opened the way toward the development of strong local and regional polities along the coast, and thereby returned the highlands to semiperipheral status.

Chavin and Chavin-inspired coastal communities had not established coercive force over their regional populations. Relying upon status alone is not sufficient to compel others to compliance. However, during the late Early Horizon and in the Early Intermediate, there exists evidence of increasing inequality in power and wealth in several settings along the Peruvian coast. In fact, the Peruvian coast became the model for one of our most influential accounts of origins of "the" state-Robert Carneiro's circumscription model.

Carneiro's model begins by hypothesizing a Peruvian coastal valley populated by small, dispersed, and autonomous villages. As population grew, villagers adapted by intensifying production and by fissioning into new locations. In time, the landscape became filled, yet population continued to grow. Since the desert boxed in fertile lands, villages then began to fight their neighbors over access to land. Formerly egalitarian and autono- 
mous villages would then become subordinate to the victors and chiefdoms would form. As population continued to grow along with military prowess, conflict between neighboring chiefdoms would persist until a single polity dominated the entire valley. States then emerged from such internecine conflict, and further growth would lead to warfare with neighboring valleys, ultimately leading to a multivalley state (Carneiro 1970).

Perhaps one reason the model seems so clear and elegant is that it was constructed in deductive style, and does not in fact come from actual archaeological evidence:

The reconstruction of these events that I present is admittedly inferential, but

I think it is consistent with the archeological evidence (Carneiro 1970:735)

A test of Carneiro's model would require thorough settlement survey archaeology of Peruvian valleys. Such survey work has in fact been carried out, and David Wilson has presented his evaluation of Carneiro's model in a number of publications (Wilson 1983; 1987; 1988; 1989; 1997; 1999).

Although Wilson's work confirms the importance of warfare in the development of complex society in the Santa Valley, it disputes the model's implications for settlement pattern and the development of valley polities. He found that the earliest agricultural villages in the Santa were not widely and thinly distributed, but rather grouped in four major aggregations, separated from one another by several kilometers, in the upper and middle parts of the valley. Each cluster appeared to be autonomous. So far, this would not seem a major deviation from Carneiro's model, so we might then expect to find warfare between sites or between clusters.

However, sites within each cluster are so immediately adjacent that warfare between them would be improbable. Between-cluster warfare would satisfy Carneiro's model of internecine conflict, but this too seems improbable in view of the data. First, clusters differ so greatly in population that his Cluster Two should have disposed of rivals rapidly. Second, both Cluster Two and Cluster One did not have sufficient irrigable land to support their populations, and each needed access to valley floor land not only between clusters Two and Three, but also farther downstream. And, as Wilson argues,"this clearly would have required cooperation among the clusters, not just among the sites that constituted them" (Wilson 1999:363). Wilson then concludes that if warfare was occurring during the Cayhuamarca Period (1000-350 B.C.E.), and the presence of a number of fortified sites suggest it was, then it was most likely not internecine warfare, but rather warfare between valleys.

On the Andean coast, I would find a model of inter-valley rather than internecine warfare plausible also because of a persistent tradition of apparently co-operative connections within valleys, as evidenced by the early construction of monumental works in the absence of any indication of hierarchy, and by the later tradition of ethnic groups defining themselves in terms of valleys.

The appearance of fortifications along with increasing valley-wide integration of settlements is one indication that warfare from this point forward will open the way toward power strategies built on coercion rather than prestige. This development reaches its culmination in this period with the emergence of what would seem to be the first indisputable state society in the Andes-the Moche state.

The most conspicuous site of the Moche Valley is at Cerro Blanco, where we find the gigantic adobe pyramid platforms known as the Huaca del Sol and the Huaca de la Luna. The Huaca del Sol measures 340 by 160 meters at its base and rises 40 meters high. Between the two huge platform mounds, recent excavations have shown dense residential rubble extending over at least one square kilometer. The summit of the Huaca del Sol also has extensive occupation debris, and a number of elite burials have also been found on lower terraces. Smaller amounts of occupation debris were found on Huaca de la Luna, but it was the site of even richer tombs than Huaca del Sol. Platforms and courts surrounded by high walls on its summit, and the remains of sacrificed individuals also indicate that it may have been the site of important rituals as well as elite residences (Wilson 1999:386-387).

With the Moche state, we are able to make more than simply good inferences about social and political organization based on settlement pattern data. Moche ceramics offer extraordinary portrayals of every aspect of life: sexual positions craft workshops, functionaries at work, warfare, sacrificial rituals, deities. Moche iconography is particularly rich and explicit in its portrayal of warriors, battle scenes, the taking of captives, and the presentation of prisoners before officials or for sacrifice. We are left with no doubt whatsoever that Moche elites commanded formidable coercive power in the form of military force.

Economic power strategies are suggested in the extensive irrigation 
systems that may well have been extended in this time. It is, however, difficult for us to be sure of the dating of the irrigation works, and we should exercise caution also by avoiding the assumption that such works required centralized management. But another instance of economic power might be seen in the massive labor mobilization required to construct the gigantic pyramids. Alfred Louis Kroeber noticed back in the 1920's that the Huaca del Sol was constructed by placing the adobe bricks into vertical columns, and he suggested that different communities were responsible for a part of the construction, "each contingent of a community building its own wall or column" (Kroeber 1930:61 as quoted in Wilson 1999:387). Such a construction technique follows, albeit on a vaster scale, the shicra technique noted in structures of the Early Preceramic.

Economic power strategies may be seen even more vividly in Moche crafts. As Wilson notes, "the superb quality of Moche weavings, pottery vessels, and metallurgy strongly suggests that state artisans were engaged fulltime in carrying out their respective craft specialties" (Wilson 1999:391). Full-time craft specialization is indicated not only by the quality of the products, but also from representations in Moche art. These include portrayals of numbers of women weaving on backstrap looms, under the apparent supervision of men in elaborate costumes doing no physical labor and represented on a scale significantly larger than the other figures in the scene (see Wilson 1999:392, figure 9.17). This makes a good case for state-sponsored craft specialization dedicated to production of wealth or status items.

As we saw earlier with the rise of the Chavin cult, new technologies were developed not to increase subsistence production or to sustain growing populations, but rather to provide status markers to support growing social inequalities. The elaborate clothing and jewels portrayed in Moche art, and found in Moche tombs, are vivid indicators of a highly stratified society.

Ideological power in the Moche state was not limited to display of exotic ritual symbols. Perhaps one of the most awe-inspiring rituals portrayed in Moche (or anywhere!) was the Moche Sacrifice Ceremony. Naked and bound men are taken to attendants who slit their throats and collect the blood in goblets. The blood-filled goblets are then presented for drinking to a figure identified from his military gear as the Warrior Priest. Perhaps we might dismiss such a blood-curdling scene as a nightmarish fantasy or a hallucinogenic vision (remember the likelihood of hallucinogens in Andean rituals). However, when Walter Alva and his colleagues excavated an intact tomb at the Sipan site, they found costumes and ritual equipment matching in detail the portrayals of the Warrior Priest. And, yes, they found the goblets as well (Alva 1988; Alva and Donnan 1993). We then have reason to believe that the Moche Sacrifice Ceremony was not simply art, but a ritual that was actually practiced. Certainly such stirring demonstrations of the power of elites served not only to impress the locals, but also were no doubt performed in valleys the Moche state conquered.

The combined ideological, economic, and, above all, military power of the Moche produced the first multi-valley state in the Andes. At its height, the Moche state (some have called it an empire) incorporated ten valleys with a combined population estimated on the order of 650,000 persons (Wilson 1999:390). Wilson's survey of the Santa Valley identified a number of features indicating Moche conquest:

+ pottery molds for mass production of ceramics in the Moche style

+ a pyramidal mound with occupation debris on the summit similar to the Huaca del Sol, and made with similar construction techniques

+ a shift in settlement pattern so that sites were moved away from high, defensible positions down to the valley floor, and fortifications were entirely eliminated

- irrigation canals were extended into the most productive downvalley areas allowing greater agricultural intensification and production of surpluses presumably for tribute

+ a large mural depicting Moche military motifs (Wilson 1999:393-397)

Building upon traditions of valley-wide co-operation established since the Early Pre-Ceramic, traditions of manipulating materializations of sacred ideology that became even more elaborated in the Chavin cult, and traditions of inter-valley warfare seen in the late Early Horizon and Early Intermediate, the Moche State combined ideological, economic, and military power strategies to build a powerful regional state that represented the core of Andean civilization.

The Late Early Horizon and Early Intermediate then culminated with the emergence of a polity with coercive power over a vast region of coastal Peru. But this too came to an end, and once again we see a shift toward a new power emerging from the highland semiperiphery. We may speculate about reasons for the Moche collapse. One plausible hypothesis invokes the all-too-frequent environmental catastrophes that loom in the Andes. 
Michael Moseley notes evidence of flood damage at the Huaca del Sol and Huaca de la Luna that may be the result of torrential El Nino rains, which were then followed by a thirty-year drought. Ice core samples from the Quelccaya ice cap indicate a severe drought from 562 to 594 C.E.. Sand then choked fields as well as irrigation canals (Moseley 1992:211; Morris and Von Hagen 1993:84).

Invoking an Andean environmental catastrophe may seem too easy a solution to the problem of collapse of the coastal state, opening the way for the emergence of the first highland conquest state. Speculation aside, I think it is sufficient to suggest that, despite its ability to organize military, economic, and ideological power in ways not previously seen in Andean civilization, the Moche State remained vulnerable. As argued above, the course of Andean civilization led to increasing integration within each of the coastal valleys. Labor mobilization for the construction of sometimes gigantic platform mounds does not seem to have been done under the command of elites, but rather seems to be done under communitarian organization. When warfare began to play a visible role in shaping polities, it did not follow the Carneiro model of internecine warfare within valleys, but rather was rivalry and conflict between valleys. Any crisis in Moche State power strategies would provide opportunity for the state to fragment into its formerly autonomous provinces.

\section{MIDDLE HORIZON (6OO-IOOO C.E.)}

The breakdown of the coastal Moche State (out of consideration for non-Andeanists, I have omitted discussion of smaller coastal states contemporary with Moche along the central and south central coast), opened the way yet again for another historic shift. Once again, the highland semiperiphery became the core of Andean civilization as large areas of the Andes were incorporated into what has been described as the first great empire of the Andes, the Wari-Tiwanaku "Empire." The dual name refers to the two central cities of this era: Wari, 2800 meters high near the modern city of Ayacucho in Peru's south central highlands, and Tiwanaku, 3850 meters high in the Andes near the southern end of Lake Titicaca in what is now Bolivia.

Tiwanaku was a massive city, extending 2.8 by 1.6 kilometers according to shard scatter, and probably much larger at its height, with an overall population estimated at 30,000-40,000 (Kolata 1993:174). The central structures at its ceremonial core are monumental platforms and enclosures incorporating the largest monolithic stone sculpture in the Andes. Stone for the sculptures and construction was quarried as far away as the Copacabana Peninsula on Lake Titicaca and transported by reed boat and overland skids (Morris and Von Hagen 1993:102). The gigantic stone sculptures and gateways and the vast patios and enclosures seem designed to mark vast ceremonial spaces.

Although we may be jumping ahead of our story, the ceremonial spaces at Tiwanaku may be ancestral to the later Inca use of space to project ideological power. As Morris and Von Hagen argue,

....intriguing parallels exist between the public architecture of Tiwanaku and that of the Inka a few centuries later. Both emphasized gateways that marked boundaries between one space and another. The Inka had great concern with such boundaries and with the movement of people across them. The ceremonial passage from one space or one patio to another may have marked important social and political transformations, and gateways themselves may have symbolized and legitimized such changes. It seems evident that the public architecture of Tiwanaku is ancestral to that of the Inka, and thus it is reasonable to suggest some of the same emphasis on ceremonial paths punctuated by gateways, shrines, and other stopping points along the way. Like the Inka, Tiwanaku rulers had to convince the people of their power and to guide the populace through a transformation establishing a new order of elites whose instructions were to be obeyed (Morris and Von Hagen 1993:103).

Further evidence of the importance of ceremony at Tiwanaku is that the artistic motifs represented on the massive gateways and sculptures became so widespread through the Andean highlands as well as the coast that it was argued that Tiwanaku must have been an expansionistic state, an empire. Alan Kolata, for example, refers to Tiwanaku as a "predatory state" (Kolata 1993:174) and as an expansionistic empire (Kolata 1993:243ff). However, to justify such an inference, we might ask what evidence we find for Tiwanaku impact on distant regions.

Tiwanaku presence in the northern Chilean desert oasis of San Pedro de Atacama is indicated by ceramics. The Tiwanaku materials are decorated with religious images characteristic of Tiwanaku's gateways. The materials also include drug paraphernalia such as the snuff trays, inhaling tubes, and spatulas found at Tiwanaku (Kolata 1993:139).

The Omo site, at Moquegua in southern Peru some 300 kilometers 
away from Tiwanaku, was the first clear instance of Tiwanaku ceremonial architecture at any distance from Tiwanaku itself (Goldstein 1989; Kolata 1993:266ff; Morris and Von Hagen 1993:108; Moseley 1992:224ff). Here Paul Goldstein found a large platform mound 120 meters long, but constructed of adobe rather than stone-faced earth. Stepped platforms and a square sunken enclosure clearly identify the site as Tiwanaku. According to Kolata, "the designers of the Omo ceremonial complex were well familiar with the architectural and sculptural tradition of Tiwanaku, and drew their inspiration directly from Tiwanaku's central monuments" (Kolata 1993: 268). A large residential area surrounded the platform, and cemeteries further out indicate a substantial population of likely Tiwanaku origin, as evidenced by the cranial deformation favored at Tiwanaku (Moseley 1992: 226-227). Kolata characterizes the Omo community as "an agricultural colony of altiplano origins" (Kolata 1993:263). Other Tiwanaku sites also "...... seem to have been constructed in sparsely occupied areas, and is very likely that they were built by peoples from the vicinity of Tiwanaku itself" (Morris and Von Hagen 1993:109).

However, I would suggest that such sites are not necessarily evidence for a Tiwanaku expansionist state, but rather that we are seeing archaeological evidence for Tiwanaku colonies. Ethnohistorical records from the Andes have shown that a number of Andean highland polities established colonies in distant environmental zones. (Murra [1972] is the classic discussion of what he called "vertical archipelagoes"). Through establishing colonies at distances as far as fifteen days walk, the home community was able to obtain desired resources without having to resort to trade, and without taking political control over intervening territories. Ethnohistorical discussion has contested whether such colonies were established late in Andean civilization, or whether, as Murra argued, they were in fact quite ancient. The archaeological materials that some cite as evidence for an expansionist Tiwanaku state seem to me to be more likely to be some of our earliest evidence for long-distance colonies.

Evidence for the "aggressive and predatory" character of the Tiwanaku polity seems to me rather thin. Iconography at the ceremonial center of Tiwanaku does include portrayals of trophy heads and sculpture apparently representing decapitation, and this, apparently, is what Kolata refers to as "aggressive, martial themes" (1993:134). However, I would ask whether in fact we should characterize trophy head themes or headhunting as necessarily "martial." Headhunting and trophy taking are characteristic of many village societies in the Amazon and in the Andes as well. I would be inclined to characterize such activities as "raiding," and I would suggest that headhunting is not a state activity. War, on the other hand, is a state activity, based on quite different logics and logistics.

Kolata seems to contradict his own characterization of Tiwanaku as an aggressive predatory state (1993:243) almost immediately after making it:

But, apart from a few exceptions, the expansion of Tiwanaku was not the product of a militaristic grand strategy worked out self-consciously by the lords of Tiwanaku and implemented through force-of-arms. Tiwanaku's empire was not of the same order of magnitude as that of the Inca, or the classical empires of the Old World, nor was its expansion primarily the work of warrior-kings with huge, standing armies ready at an instant to conquer, intimidate, and oppress local populations. Military stratagems and conscious efforts to conquer territory played a relatively small role in the movement of Tiwanaku into foreign territories. Rather, we must think of the state as a dynamic mosaic of populations linked at times imperfectly by a mosaic of strategic policies and political relationships devised by Tiwanaku's elite interest groups in an almost ad hoc fashion. These political stratagems responded to local cultural diversity and specific historical contingencies (Kolata 1993:243)

In other words, Tiwanaku did not project its power through military means, and at numerous points Kolata argues that coercive force was not necessary, but rather that "Tiwanaku state religion and imperial ideology performed much the same work as military conquest, but at significantly lower cost" (1993:245, 246, 252, 82, 85).

The absence of military motifs, military architecture, or occupation of previously occupied territories with consequent changes in settlement pattern also speaks to me of something other than a conquest state. What it does suggest, in my view, is another widespread Andean cult in many ways reminiscent of the Early Horizon Chavin cult. Tiwanaku iconography in many cases resembles Chavin, and, as Isbell notes, "there can be little doubt that Tiahuanacoid iconography belongs to a mythical tradition with its roots in late Chavin culture" (Isbell 1988:180). The prominence of ceremonial space and even the spread of drug paraphernalia also seem to echo Chavin. Again, as Kolata argues, "an essential element of Tiwanaku imperial policy was the exportation of state cults" (1993:248). Apart from dissemination of 
images of the Gateway God, Tiwanaku craft items were mass-produced for export to colonies as prestige items and status markers associated with the religious ideology of Tiwanaku.

Where Tiwanaku also seems to have built upon post-Chavin core civilization is in a mobilization of economic power beyond anything seen in the Early Horizon. Apart from the massive scale of Tiwanaku, so vast that it must be characterized as a city rather than simply a ceremonial center, the Tiwanaku polity transformed agricultural production in a manner comparable to the great coastal irrigation works.

Tiwanaku is situated at a higher altitude than any ancient city in the world, and its population seems to have been far too large to have been sustained by agricultural techniques typically available at such altitude. However, Tiwanaku relied on extraordinary agricultural techniques to intensify production. Along the shore of Lake Titicaca, 75 square kilometers of raised fields constructed on platforms from 5 to 15 meters wide and up to 200 meters long allowed the high yields necessary to sustain a city of Tiwanaku's magnitude (Kolata 1993:183ff presents a detailed accounting of Tiwanaku agricultural technology; see also Moseley 1992:229; Morris and Von Hagen 1993:105).

In sum, I would argue that Tiwanaku built upon the forms of ideological power spread under the Chavin cult during its time as a highland core region, and it built upon strategies of economic power expanded in the coastal core regions. What seems less convincing is that it exercised military power, and for that reason I am disinclined to speak of a Tiwanaku "empire." Nonetheless, this discussion of Middle Horizon began with reference to the Wari-Tiwanaku "Empire," and I believe that we do find evidence of the combination of ideological, economic, and military power strategies in Wari.

Wari's urban core, on the eastern edge of the Ayacucho Valley, sprawled over an area of 3-4 square kilometers with a population on the order of 20,000-30,000 (Moseley 1992:217). Massive stone walls divide Wari into sectors containing numerous building compounds ranging in size from 40 meters to 100 meters in length, and often reaching two or three stories high (Isbell 1988:168-169). Such a large and dense population was made possible because of a very large irrigation system and extensive terracing of steep slopes to increase the available productive lands. By putting steep slopes into production for the first time, and by drawing irrigation water from elevated springs or streams less vulnerable to irregular rainfall patterns (Moseley 1992:218), Wari economic power strategies represent yet another example of new technologies appearing in formerly semiperipheral regions.

Ideological power was materialized in Wari's adoption of some of the most important religious symbols from Tiwanaku, such as the Gateway God (which itself may have been derived from the Chavin Staff God). Wari iconography shares so much with Tiwanaku that they were once thought to be dual capitals of a single empire. However, one finds a number of significant differences between Tiwanaku and Wari iconography. Tiwanaku iconography was depicted largely on monumental stone objects, while Wari iconography was represented primarily on portable objects that could be taken out to the wider world (Schreiber 1992:280). In contrast to Tiwanaku, where vast open ceremonial spaces seemed to invite pilgrims to come into the city, Wari architecture is closed and in many instances bafflingly inaccessible. The message appears to be "You need not come to Wari, but Wari will come to you!"

Wari's propensity to extend itself outward is seen in a string of a dozen major administrative centers outside the Wari heartland, stretching some 1000 kilometers from Cuzco to Cajamarca. Three of these Wari provincial centers have been excavated sufficiently to give some picture of how Wari outliers worked. The smallest, Jincamocco, covers about four hectares in the Carhuarazo Valley, six days away from Wari. Schreiber argues that it was a major administrative center, and three smaller centers were built on the other side of the valley. As she writes, "The Wari occupation of this valley resulted in an alteration of local lifestyles so revolutionary that some of those changes still affect life there today" (Schreiber 1992:259). It appears to have been situated along a road extending through Jincamocco to the coast (Schreiber 1992:261) (Isbell 1988:185).

Two larger centers suggest a forceful Wari presence at great distance from Wari itself. Viracochapampa, in the highlands near Cajamarca some 700 kilometers north of Wari, is a vast rectangular compound measuring more than half a kilometer on a side. Within the compound walls enclosing a space larger than 30 hectares are numerous courts, patios, and structures surrounding a central plaza (Moseley 1992:223). It is not clear that Viracochapampa can be taken as evidence of military conquest so far north of Wari, but it does demonstrate Wari's farthest reach northward (Topic1991). 
Pikillaqta, in the Cuzco Valley some 250 kilometers southeast of Wari, is the southernmost and largest of the Wari centers. In fact, the extent of Pikillaqta is as large as the core of Inca Cuzco (McEwan 1991:93). Within this space we find enormous rectangular compounds and vast warrens of rooms that appear to have been storage facilities and barracks-like quarters (Morris and Von Hagen 1993:116; Isbell 1988:185). Following some of the most recent investigations at Pikillaqta, McEwan concludes:

...Pikillacta represents a very sophisticated, complex product of a highly organized society. It was probably built to house a political and religious elite who administered the southern highland part of the Huari empire, and to concentrate in one place the economic and political functions together with a resident local population in order to centralize this provincial administration (McEwan 1991:118).

Although Wari compounds, particularly Pikillaqta, have been characterized as garrisons, the outer walls at Pikillaqta "lack parapets, ascending steps, and other features characteristic of fortifications" (Isbell 1988:185) (for discussion of how we may identify military architecture in the Andes, see Topic and Topic 1987). Nonetheless, Wari structures were such formidable strongpoints that it seems implausible that they would be vulnerable to anything less than massive force.

Our most direct view of Wari military organization comes from Cerro Baul, a 600 meter high mesa in the Moquegua Valley, where we have earlier encountered the Tiwanaku Omo colony situated some 20 kilometers away. The route up Cerro Baul was fortified with walls and parapets, and its summit was covered with a large complex of Wari buildings (Moseley 1992:221). The construction of such a formidable fortified site gives us some idea of what Wari was capable of when it moved into territory contested by a potentially powerful adversary (Moseley, et al. 1991). Formidable fortifications in the Moquegua Valley zone where Wari and Tiwanaku seem to have come in direct confrontation might expectably differ from what we might see in Wari provincial sites between Pikillaqta and Viracochapampa where there were no rivals so potentially powerful as Tiwanaku. As Schreiber evaluates the thousand-kilometer string of Wari highland sites and evidence for sometimes "revolutionary" changes in local lifestyles, she concludes that ...available data are consistent with the interpretation that Wari was an imperialist state. It controlled a very large territory, from Cuzco to Cajamarca in the highlands, and possibly the coast as well. It was a territory that was ethnically and ecologically diverse. It expanded very rapidly, and lasted perhaps only 150 years. Above all, there is good evidence of direct Wari political control over a series of discrete regions;... (Schreiber 1992:267)

Whatever we may make of evidence for Wari as a conquest state, I believe that Wari demonstrated its economic power by reorganizing agricultural production in its provincial sites through terracing, irrigation, and promotion of maize agriculture. The substantial storage facilities in Wari sites also indicate formidable surplus production. Wari also projected ideological power, though primarily in the form of imagery taken from Tiwanaku. Finally, we have some indication that Wari was able to plant sites over a distance on the order of a thousand kilometers, and this in itself suggests that it was able to handle any objections from the locals. But Tiwanaku and Wari world collapse.

"After approximately 700 years of growth and colonial expansion, the Tiwanaku state disappeared as a regional political force in the south-central Andes between A.D. 1000 and 1100." (Kolata 1993:284) Collapse of Tiwanaku seems to be closely correlated with yet another Andean environmental disaster. Data from the Quelccaya glacier indicate that a major drought began around 1000 C.E. and lasted for decades. During the drought, the canal-based irrigation in the Moquegua Valley and the groundwater-based irrigation agriculture on the Peruvian and Chilean coasts failed (Kolata 1993:294; Clement and Moseley 1989). The raised ridged fields in the Tiwanaku heartland were initially less vulnerable to degradation from the drought, but in time the lowering water table had a devastating impact there as well. Abandonment of many of the Tiwanaku outliers followed collapse of Tiwanaku's agricultural base, and cities and urban civilization disappeared in the Titicaca Basin for another 400 years (Kolata 1993:299). The successors to Tiwanaku retreated into sites, often fortified, where access to water could be defended.

For the Wari collapse, I would propose another scenario. Wari had been unable to move toward the Titicaca Basin because of Tiwanaku's presence to the south. Wari did try to challenge Tiwanaku in the Moquegua Valley, as we see at Cerro Baul, but apparently withdrew. Blocked to the south, Wari moved as far as it could into the Cuzco Basin and as far south from 
there as Sicuani, where it met the northern most extension of Tiwanaku (evidence: Canas and Canchis were formerly Aymara speakers, according to Cieza). From the Cuzco region, Wari extended northward along the sierra as far north as the Cajamarca region. A one thousand kilometer long stretch would be difficult to sustain without military superiority and good supply lines. Evidence suggests that Wari built a road system and established storage and rest facilities along the route.

However, already overextended, Wari would also be vulnerable to any environmental catastrophe. The collapse of Wari, as well as that of Tiwan$\mathrm{aku}$, and, for that matter, of all previous Andean civilizations did not mean a return to scattered tribal villages. The successor polities continued to exercise economic, military, and, presumably, ideological power, albeit on a smaller scale. The small successor polities to the Middle Horizon regional polities often took the form of hill-fort chiefdoms (see Earle 1997:121), and such polities were characteristic in the Andes in the Late Intermediate Period.

\section{LATE INTERMEDIATE AND THE EMERGENCE OF THE INCA STATE}

The period following the collapse of the Middle Horizon is known as the Late Intermediate Period. Once again, the core polities, Wari and Tiwanaku, collapsed and what had been their semiperipheral provinces broke away and formed what Earle refers to as hill-fort chiefdoms all throughout the highlands. The Late Intermediate chiefdoms are conspicuous archaeologically for their hilltop fortifications, and the oral traditions carried into the ethnohistorical literature reinforce the argument that their power was all but exclusively military. Each chiefdom was led by a sinchi, and documents from throughout the Andean highlands make it clear that a sinchi was a warrior chief.

In the absence of demographic disparities, and given the simplicity of the weapons of war, what we would expect to find is a situation of military stand-off. However, it is out of this situation and this era that we see the rapid rise of what would become the greatest empire of the Americas, and certainly one of the most extensive of all ancient empires. Discussion of the Late Intermediate and the rise of the Inca state is not to be undertaken as a few concluding pages of a hasty survey of Andean civilization. It is a monumental story, and I wouldn't dare even to outline it here. However, I would conclude with a speculative prospectus for the next part of the story.

Toward the end of the Middle Horizon, Wari, unable to move south, had moved north and was dangerously overextended. At any point between Cuzco and Cajamarca, a belligerent chiefdom may have found opportunity to challenge the Wari presence. One such warrior group who dominated parts of Ayacucho, Huancavilca, and Andahuaylas were known as the Chancas. In the scenario I propose, the Chancas were the ones whose challenge dismantled the Wari state. Following victory over Wari, the Chancas then moved, as had Wari before at Pikillaqta, toward the Cuzco Valley.

This, however, proved a fatal error, or perhaps only bad luck in historical contingency, since, certainly against Chanca expectations and those of many in Cuzco as well, the Cuzco forces defeated the Chancas. The military success of Cuzco is the defining moment for the emergence of Cuzco as an expansionistic state. Following consolidation of the Cuzco region, perhaps it should not be surprising that the new Inca state would soon move toward the south. Without the opposition of Wari or Tiwanaku states, Cuzco could control the entire length of the Vilcanota Valley, and move to take the altiplano regions that were formerly the Tiwanaku heartland.

And what were they after? We have no evidence suggesting that the Inca restored the vast ancient raised fields. What the Titicaca Basin meant for the Inca was a vast pastureland and vast herds of camelids. With llamas carrying the loads in supply caravans, the Inca were able to expand upon Wari techniques of road extension with waystations as points for storage, labor mobilization, military garrison, and state displays.

From the semiperiphery, the Cuzco Valley, then rose the greatest Empire of the ancient Americas. Its economic power transformed the Andes both in the highlands and on the coast as it reorganized agricultural production, mobilized labor throughout its entire reach, and constructed a vast network of state storage facilities. It skillfully manipulated ideological power as it imposed new state cults and co-opted local deities. And, most conspicuously, it was able to organize military power on a scale without precedent in the Andes. As Earle puts it,

The changes accompanying the rapid Inka expansion ....involved weaving a tapestry of power that united the powers of military, economy, and ideology. Warfare became effective as it became supported by a state financial system and institutionalized by a state ideology. The destructive power of military might was fashioned into an effective political source of centralizing power in 
Peru only when it was harnessed and controlled through its articulation with the other sources of power (Earle 1997:122)

\section{SUMMARY AND CONCLUSIONS}

Collapse and succession in Andean world-systems follow patterns and rhythms common to other ancient world-systems. Although they were not the first to do so, anthropologists and archaeologists have returned to this problem over the past fifty years (e.g. Steward 1949, Willey 1991, Marcus 1998, Chase-Dunn and Hall 1997).

Particularly powerful hypotheses for regularities in collapse and succession come from an understanding of geopolitical principles. I have argued in this paper that effective exercise of power requires organization of economic, ideological, and military power. But, following Collins, "the state consists ultimately of military control over a territory" (Collins 1981:71). To elaborate on this rather stark statement of necessary conditions for a successful state, Collins draws our attention to "the organizational resources that make up the bases of military power, and the territorial configurations in which this power is exercised" (Collins 1981:71).

Discussion of the organizational resources underlying military power is fundamental in current archaeological and anthropological treatments of complex society (e.g., Earle 1977). What is missing in many works, however, is study of the territorial configurations in which power is exercised. Once states have filled landscapes, a number of geopolitical principles come into play without regard to cultural particularities. Some of the issues Collins directs us toward include, weponry, heartland size and wealth, marchland advantages, overxpansion, and technological diffusion (1981:75, 80, 98, 101)

I believe archaeologists and anthropologists may find richer understanding of the organization of power through closer study of what we have learned from geopolitics and military history. As in chess, the better we understand the territory, the more likely we are to find meaningful patterns and strategies in the middle and end games. Archaeology, apart from a flirtation with central place theory, has not deeply explored the geography of power. As Collins argues, our task is to understand "the organizational resources that make up the bases of military power, and the territorial configurations in which this power is exercised" (Collins 1981:71). Although
I have agreed with the argument that without military power a polity has little chance of success, military power is not the whole story. Leaving the last word to Earle,

A strong central political institution depends less on any one source of power than on the interrelationships among the power sources and on its ultimate grounding in the political economy. (Earle 1997:192)

\section{REFERENCES}

Adams, Robert Mc. (1966). The Evolution of Urban Society: Early Mesopotamia and Prehispanic Mexico. Chicago: Aldine.

Alva, Walter (1988). “Discovering the New World's Richest Tomb," National Geographic 174(4):510-523.

Alva, Walter, and Christopher B. Donnan (1993). Royal Tombs of Sipan. Los Angeles: Fowler Museum of Cultural History.

Blanton, Richard E. (1998)."Beyond Centralization, Steps Toward a Theory of Egalitarian Behavior in Archaic States," in Archaic States. Gary M. Feinman and Joyce Marcus, eds. Santa Fe: School of American Research Press.

Burger, Richard L. (1988). "Unity and Heterogeneity Within the Chavin Horizon." in Peruvian Prehistory. Richard W. Keatinge, ed. Pp. 99-144. Cambridge: Cambridge University Press.

Burger, Richard L. (1995). Chavin and the Origins of Andean Civilization. New York: Thames and Hudson.

Carneiro, Robert (1970). A Theory of the Origin of the State. Science 169:733-738.

Chase-Dunn, Christopher, and Thomas D. Hall (1997). Rise and Demise, Comparing World-Systems. Boulder: Westview Press.

Clement, C., and M. Moseley (1989). "Agricultural Dynamics in the Andes," in Ecology, Settlement, and History in the Osmore Drainage, Peru. D. Rice, C. Stanish and P. Scarr, eds. Pp. 435-455. Oxford: British Archaeological Reports International Series 545(ii).

Collins, Randall (1981)."Long-Term Social Change and the Territorial Power of States." in Sociology Since Midcentury: Essays in Theory Cumulation. Randall Collins, ed. New York: Academic Press.

Colson, Elizabeth (1977)."A Continuing Dialogue:Prophets and Local Shrines Among the Tonga of Zambia". in Regional Cults. R.P. Werbner, ed. Pp. 119-139. New York: Academic Press.

Conklin, W. J. (1978). The Revolutionary Weaving Inventions of the Early Horizon. Nawpa Pacha 16:1-12.

Culbert, T. Patrick, ed. (1973). The Classic Maya Collapse. Albuquerque: University of New Mexico Press.

Earle, Timothy (1997). How Chiefs Come to Power. Stanford: Stanford University Press.

Goldstein, Paul (1989). Omo, a Tiwanaku Provincial Center in Moquegua, Peru. Ph.D. dissertation, Chicago: The University of Chicago. 
Haas, Jonathan, Shelia Pozorski, and Thomas Pozorski (1987). The Origins and Development of the Andean State. Cambridge: Cambridge University Press.

Isbell, William (1988). “City and State in Middle Horizon Huari," in Peruvian Prehistory. Richard W. Keatinge, ed. Pp. 164-189. Cambridge: Cambridge University Press.

Johnson, Allen W, and Timothy K. Earle (1987). The Evolution of Human Societies: From Foraging Group to Agrarian State. Palo Alto: Stanford University Press.

Jones, Grant D., and Robert R. Kautz (1981). The Transition to Statehood in the New World. Cambridge: Cambridge University Press.

Kolata, Alan L. (1993). The Tiwanaku: Portrait of an Andean Civilization. Cambridge, MA: Blackwell.

Kroeber, Alfred (1930)."Archaeological Explorations in Peru, Part II: The Northern Coast." Field Museum of Natural History, Anthropology Memoirs 2(2).

Lechtman, Heather (1980). "The Central Andes:Metallurgy Without Iron." in The Coming of the Age of Iron. T Wertime and J. Muhly, eds. Pp. 267-334. New Haven: Yale University Press

Mann, Michael (1986). The Sources of Social Power. Vol. I. A History of Power from the Beginning to A.D. 1760. Cambridge: Cambridge University Press.

Marcus, Joyce J. (1989) "From Centralized Systems to City-States: Possible Models for the Epi-Classic." in Mesoamerica After the Decline of Teotibuacan, A.D. 700-900. Richard A. Diehl and Janet C. Berlo, eds. Pp. 201-208. Washington, D.C.: Dumbarton Oaks.

Marcus, Joyce J (1998).“The Peaks and Valleys of Ancient States, An Extension of the Dynamic Model," in Archaic States. Gary M. Feinman and Joyce Marcus, eds. Pp. 59-94. Santa Fe: School of American Research Press.

Marcus, Joyce, and Gary M. Feinman (1998). "Introduction." in Archaic States. Gary M. Feinman and Joyce Marcus, eds. Pp. 3-13. Santa Fe: School of American Research Press.

McEwan, Gordon F. (1991) "Investigations at the Pikillacta Site: A Provincial Huari Center in the Valley of Cuzco," in Huari Administrative Structure. William H. Isbell and Gordon F. McEwan, eds. Pp. 93-119. Washington, D.C.: Dumbarton Oaks.

Millon, René (1988). "The Last Years of Teotihuacan Dominance." in The Collapse of Ancient States and Civilizations. Norman Yoffee and George L. Cowgill, eds. Pp. 102-164. Tucson: University of Arizona Press.

Morris, Craig, and Adriana Von Hagen (1993). The Inka Empire and Its Andean Origins. New York: Abbeville Press.

Moseley, Michael (1992). The Incas and Their Ancestors. London: Thames and Hudson.

Moseley, Michael, Robert A. Feldman, Paul Goldstein, and Luis Watanabe (1991) "Colonies and Conquest: Tiahuanaco and Huari in Moquegua," in Huari Administrative Structure. William H. Isbell and Gordon F. McEwan, eds. Pp. 121-140. Washington, D.C.: Dumbarton Oaks.
Murra, John V. (1972)."El Control Vertical de un Maximo de Pisos Ecologicos en la Economia de las Sociedades Andinas." in Visita de la Provincia de Huanuco, Vol. 2. John V. Murra, ed. Pp. 427-476. Huanuco, Peru: Universidad Nacional Hermilio Valdizan.

Schreiber, Katharina J. (1987). "From State to Empire: The Expansion of Wari Outside the Ayacucho Basin," in The Origins and Development of the Andean State. Jonathan Haas, Shelia Pozorski and Thomas Pozorski, eds. Pp. 91-96. Cambridge: Cambridge University Press

Schreiber, Katharina J. (1992). "Wari Imperialism in Middle Horizon Peru," University of Michigan Museum of Anthropology Anthropological Papers N0. 87.

Service, Elman Rogers (1975). Origins of the State and Civilization: The Process of Cultural Evolution. New York: Norton.

Steward, Julian (1949)."Cultural Causality and Law: A Trial Formulation of the Development of Early Civilizations," American Anthropologist 51:1-27.

Steward, Julian (1955). Theory of Culture Change: The Methodology of Multilinear Evolution. Urbana: University of Illinois Press.

Tainter, Joseph A. (1988). The Collapse of Complex Societies. Cambridge: Cambridge University Press.

Toland, Judith D. (1987). "Discrepancies and Dissolution: Breakdown of the Early Inca State," in Early State Dynamics. Henri J. M. Claessen and van de Velde, eds. Pp. 138-153. Leiden: Brill.

Topic, John (1991)."Huari and Huamachuco," in Huari Administrative Structure. William H. Isbell and Gordon F. McEwan, eds. Pp. 141-164. Washington, D.C. Dumbarton Oaks.

Topic, John, and Theresa Topic (1987)."The Archaeological Investigation of Andean Militarism:Some Cautionary Observations," in The Origins and Development of the Andean State. Jonathan Haas, Shelia Pozorski and Thomas Pozorski, eds. Pp. 47-55. Cambridge: Cambridge University Press.

Willey, Gordon R. (1991)."Horizontal Integration and Regional Diversity: An Alternating Process in the Rise of Civilizations," American Antiquity 56:197-215.

Wilson, David J. (1981)."Of Maize and Men:A Critique of the Maritime Hypothesis of State Origins on the Coast of Peru," American Anthropologist 83:93-120.

Wilson, David J. (1983).“The Origins and Development of Complex Prehispanic Society in the Lower Santa Valley: Implications for Theories of State Origins," Journal of Anthropological Archaeology 2:209-276.

Wilson, David J. (1987). "Reconstructing Patterns of Early Warfare in the Lower Santa Valley: New Data on the Role of Conflict in the Origins of Complex North Coast Society," in Origins and Development of the Andean State. Jonathan Haas, Shelia Pozorski and Thomas Pozorski, eds. Pp. 56-69. Cambridge: Cambridge University Press. 
Wilson, David J. (1989).“Full-Coverage Survey in the Lower Santa Valley: Implications for Regional Settlement Pattern Studies on the Peruvian Coast," in The

Archaeology of Regions: The Case for Full-Coverage Regional Survey. Suzanne Fish and Steven Kowalewski, eds. Pp. 117-145. Washington, D.C.: Smithsonian

Institution Press.

Wilson, David J. (1997)."Early State Formation on the North Coast of Peru: A

Critique of the City-State Model," in The Archaeology of City-States:Cross-

Cultural Approaches. Deborah Nichols and Thomas Charlton, eds. Pp. 229-244.

Washington, D.C.: Smithsonian Institution Press.

Wilson, David J. (1999). Indigenous South Americans of the Past and Present. Boulder: Westview Press.

Wittfogel, Karl (1957) Oriental Despotism: A Comparative Study of Total Power. New Haven: Yale University Press.

Wright, Henry T., and Gregory A. Johnson (1975)."Population, Exchange, and Early State Formation in Southwestern Iran," American Anthropologist 77:267-289.

Yoffee, Norman (1995)."Political Economy in Early Mesopotamian States," Annual Review of Anthropology 24:281-311.

Yoffee, Norman, and George L. Cowgill (1988). The Collapse of Ancient States and Civilizations. Tucson: University of Arizona Press. 